\section{Salinity Interactions with Other Abiotic and Biotic Stresses in Citrus}

\author{
Jim Syvertsen ${ }^{1}$ and \\ Yoseph Levy ${ }^{2}$
}

\begin{abstract}
Additional Index words. drought stress, elevated $\mathrm{CO}_{2}$, high temperature, root rot, mycorrhizae, nematodes, osmotic stress, VPD, water use
\end{abstract}

SumMARY. Multiple stresses almost always have synergistic effects on plants. In citrus, there are direct and indirect interactions between salinity and other physical abiotic stresses like poor soil drainage, drought, irradiance, leaf temperature, and atmospheric evaporative demand. In addition, salinity interacts with biotic pests and diseases including root rot (Phytophthora spp.), nematodes, and mycorrhizae. Improving tree water relations through optimum irrigation/drainage management, maintaining nutrient balances, and decreasing evaporative demand can alleviate salt injury and decrease toxic ion accumulation. Irrigation with high salinity water not only can have direct effects on root pathogens, but salinity can also predispose citrus rootstocks to attack by root rot and nematodes. Rootstocks known to be tolerant to root rot and nematode pests can become more susceptible when irrigated with high salinity water. In addition, nematodes and mycorrhizae can affect the salt tolerance of citrus roots and may increase chloride $\left(\mathrm{Cl}^{-}\right)$uptake. Not all effects of salinity are negative, however, as moderate salinity stress can reduce physiological activity and growth, allowing citrus seedlings to survive cold stress, and can even enhance flowering after the salinity stress is relieved.

S alinity stress rarely occurs when all other environmental factors are at optimum levels. For example,

\footnotetext{
This research was supported by the Florida Agricultural Experiment Station, and approved for publication as Journal Series No. R-09847.

${ }^{1}$ University of Florida, IFAS, Citrus Research and Education Center, 700 Experiment Station Road, Lake Alfred, FL 33850. To whom reprint requests should be addressed; e-mail: jmsn@crec.ifas.ufl.edu

${ }^{2}$ ARO, Gilat Experiment Station, Mobile Post Negev, 85280 Israel.
}

salinity stress often occurs with poor soil drainage and/or high temperature stress. There are direct interactions between salinity, leaf water relations, irradiance, leaf temperature, and atmospheric evaporative demand that are impossible to separate in the field. Physiological mechanisms underlying environmental interactions with salinity can only be studied in controlled environments where individual stresses and their two-way interactions can be described. Such studies may provide insights into cultural practices or environmental conditions that can improve production under salinity stress. There are few studies on interactions between salinity and biotic stresses since controlled environment studies on salinity are most often carried out in a pest-free environment so that potentially complicating interactions between biotic stresses and salinity can be avoided. As part of a workshop entitled "Response of Citrus to Salinity," this report will focus on interactions between salinity stress and physical and biotic stresses in citrus. This short review has been derived from a recent extensive review (Levy and Syvertsen, 2004) and will focus on interactions of salinity stress with high temperature, evaporative demand, elevated carbon dioxide $\left(\mathrm{CO}_{2}\right)$, drought/osmotic stress, and nutritional imbalances along with salinity stress effects on fungal diseases and pests that attack citrus roots. Although salinity is not beneficial for citrus in the long run, short-term potential benefits of moderate salinity will also be discussed.

\section{Salinity interactions with abiotic physical environmental factors}

High temperature AND EVAPORative Demand. Multiple stresses almost always have synergistic effects on plants. Citrus leaves growing in full sun can experience midday temperatures that exceed air temperature by as much as $9^{\circ} \mathrm{C}\left(16.2^{\circ} \mathrm{F}\right)$ (Syvertsen and Albrigo, 1980). Leaf temperatures up to $45^{\circ} \mathrm{C}\left(113.0^{\circ} \mathrm{F}\right)$ not only enhance respiratory rates and exceed optimum temperature for photosynthesis, but also lead to large vapor pressure differences (VPD) between leaves and air. Transpirational water use is driven by VPD, so large VPDs can result in very low water use efficiency (WUE). Citrus leaf stomata are sensitive to evaporative demand, however, so a large VPD can reduce stomatal conductance $\left(\mathrm{g}_{\mathrm{s}}\right)$ and net assimilation of $\mathrm{CO}_{2}\left(\mathrm{~A}_{\mathrm{CO}_{2}}\right)$ (Jifon and Syvertsen, 2003a). Decreasing VPD by lowering leaf temperature or increasing humidity can increase $\mathrm{g}_{\mathrm{s}}$, $\mathrm{A}_{\mathrm{CO}_{2}}$, and WUE without increasing total water use. Since $\mathrm{Cl}^{-}$carried in the transpiration stream remains in leaves after water evaporates, leaf $\mathrm{Cl}^{-}$accumulation has been linked to water use in citrus rootstocks (Moya et al., 2003). Misting leaves with high quality water can improve salinity tolerance and decrease accumulation of toxic ions in tomato (Lycopersicon esculentum) plants (Romero-Aranda et al., 2002). Since salinity stress is usually greater for sun-exposed than for shaded leaves, additional shade may improve salinity tolerance. Artificial shade screens (Jifon and Syvertsen, 2001) or foliar sprays of kaolin clay particle film (Jifon and Syvertsen, 2003b) during the warmest season reduced citrus leaf temperature and improved WUE. Properly timed artificial shade, therefore, may decrease salt stress.

Elevated $\mathrm{CO}_{2}$. Rapidly growing plants almost always use more water than slower growing plants. In citrus, many vigorous rootstocks that produce fast-growing trees also tend to have poor salt tolerance (Castle et al., 1993). In addition, $\mathrm{Cl}^{-}$absorption in the relatively salt sensitive Carrizo citrange (Citrus sinensis x Poncirus trifoliata) and in the more salt-tolerant Cleopatra mandarin (C. reticulata) has been linked to their water use (Moya et al, 2003). Thus, there can be a link between high water use and low salinity tolerance. Growing plants at elevated $\mathrm{CO}_{2}$ usually increases growth and $\mathrm{A}_{\mathrm{CO}_{2}}$, but at the same time high $\mathrm{CO}_{2}$ decreases stomatal conductance and water use. Thus, elevated $\mathrm{CO}_{2}$ almost always leads to higher WUE as it disconnects rapid tree growth from high water use. Growing citrus under conditions of elevated $\mathrm{CO}_{2}$, therefore, offers a tool to study mechanisms of salinity tolerance. If salt uptake is coupled with water uptake, then leaves grown at elevated $\mathrm{CO}_{2}$ should have lower salt concentrations than leaves grown at ambient $\mathrm{CO}_{2}$ (Ball and Munns, 1992). On the other hand, if ion accumulation is related to growth, then growing plants in elevated $\mathrm{CO}_{2}$ should increase ion accumulation. In greenhouse studies of salinity tolerance of citrus rootstock seedlings, Rangpur lime (C. reticulata) and Cleopatra mandarin were less affected by salinity stress 
than were sour orange (C. aurantium) and sweet orange (C. sinensis) (J. Syvertsen and J. Grosser, unpublished). As expected, all citrus rootstock species studied increased growth and WUE in response to elevated $\mathrm{CO}_{2}$ that was twice ambient. Generally, the salinityinduced accumulation of sodium $\left(\mathrm{Na}^{+}\right)$ in leaves was less when seedlings were grown at elevated $\mathrm{CO}_{2}$ than at ambient $\mathrm{CO}_{2}$, implying that the lower $\mathrm{Na}^{+}$ accumulation was linked to increased WUE. $\mathrm{Na}^{+}$accumulation, however, was unaffected by elevated $\mathrm{CO}_{2}$ in relatively salt-tolerant Rangpur lime. Rangpur lime also had the lowest leaf $\mathrm{Cl}^{-}$concentrations and leaf $\mathrm{Cl}^{-}$was unaffected by growing in elevated $\mathrm{CO}_{2}$ in Rangpur lime. The accumulation of leaf $\mathrm{Cl}^{-}$in salinized sour orange was greater at elevated $\mathrm{CO}_{2}$ than at ambient $\mathrm{CO}_{2}$, implicating a link between growth and $\mathrm{Cl}^{-}$accumulation in leaves. Leaf $\mathrm{Cl}^{-}$concentrations in Cleopatra mandarin, however, were less at elevated $\mathrm{CO}_{2}$ than at ambient conditions. Thus, the decrease in $\mathrm{Cl}^{-}$accumulation at elevated $\mathrm{CO}_{2}$ in Cleopatra mandarin was related to the increase in WUE, whereas the increase in leaf $\mathrm{Cl}^{-}$in sour orange was not. Contrasting patterns of $\mathrm{Na}^{+}$ and $\mathrm{Cl}^{-}$imply these ions accumulate by different transport pathways and relationships between ion accumulation and water use differ in different Citrus species.

Drought, OSMOTIC STRESS, AND TOXIC ION ACCUMULATION. Salinity affects citrus in two ways: osmotic stress and toxic ion stress. Dissolved salts exert an osmotic effect that reduces the availability of free (unbound) water through physical processes. This situation is analogous to drought stress that lowers leaf water potential. Growth and yield of all plants is reduced by decreased leaf water potential (Maas, 1986). The effect of osmotic stress is different when stress increases gradually, allowing the plant to adjust, compared to the situation when osmotic stress in the soil solution increases abruptly (Levy and Syvertsen, 2004). When salinity stress is gradual, salttolerant rootstocks, which limit the translocation of the toxic ions $\mathrm{Cl}^{-}$and $\mathrm{Na}^{+}$into the leaves, will acclimate to osmotic stress in the root zone by closing stomata and reducing transpiration (Nieves et al., 1991; Syvertsen and Smith, 1983). In contrast, osmotic shock can occur from a rapid increase in salinity of the soil solution, such as results from excessive fertilization or when a light rain leaches accumulated salts into the root zone (Levy and Syvertsen, 2004). Osmotic shock, induced either by a sudden salt increase or severe drought stress, increased abscisic acid (ABA), ethylene production, and leaf abscission (Gomez-Cadenas et al., 1998). Following such a shock, the lamina (leaf blade) typically separates at the abscission zone between the lamina and the petiole. The petiole may remain green and attached to the stem for some time. After such events, leaf analysis of the abscised leaves may not reveal an increase in $\mathrm{Cl}^{-}$or $\mathrm{Na}^{+}$ content. It is possible that the transitory ethylene rises are first induced by the osmotic component of salinity and then by $\mathrm{Cl}^{-}$accumulation. The addition of ABA to the nutrient solution before exposure to salt stress, reduced ethylene release and leaf abscission. In non-salinized plants, $\mathrm{ABA}$ reduced $\mathrm{g}_{\mathrm{s}}$ and $\mathrm{A}_{\mathrm{CO}_{2}}$, whereas in salinized plants the $\mathrm{ABA}$ treatment slightly increased net gas exchange. These results suggest a protective role for $\mathrm{ABA}$ in citrus under salinity stress (Gomez-Cadenas et al., 2002).

The effect of salinity on plant growth is not only related to osmotic effects, but growth reductions in citrus also can be related to a gradual accumulation of toxic levels of $\mathrm{Cl}^{-}, \mathrm{Na}^{+}$, or boron (B) in leaves. In most plant species, the accumulation of $\mathrm{Na}^{+}$is often a greater concern than the accumulation $\mathrm{Cl}^{-}$. Citrus may be relatively unique in this respect since $\mathrm{Cl}^{-}$accumulation in citrus leaves is often a greater concern than $\mathrm{Na}^{+}$accumulation. $\mathrm{Na}^{+}$toxicity can be important in some rootstocks, however, especially in salinity experiments that do not incorporate sufficient calcium $\left(\mathrm{Ca}^{+}\right)$(Rengel, 1992). Soil $\mathrm{Na}^{+}$ displaces $\mathrm{Ca}^{+}$to potentially deficient levels as $\mathrm{Ca}^{+}$is required to maintain cell membrane integrity. One of the main differences between the effects of salinity on annual plants and trees is that the gradual accumulation of toxic elements in leaves and other plant parts in trees can be cumulative over several years (Shalhevet and Levy, 1990). As discussed above, these elements are transported by the transpiration stream and remain in the plant after transpired water has evaporated.

Nutrient imbalances. Salinity can cause nutrient imbalances in several ways. Potassium $\left(\mathrm{K}^{+}\right)$can be leached from the soil exchange complex if excessive $\mathrm{Na}^{+}$is present, and $\mathrm{Na}^{+}$may also compete with $\mathrm{K}^{+}$at the soil-root interface. High nitrate $\left(\mathrm{NO}_{3}\right)$ from potassium $(\mathrm{K}) \mathrm{NO}_{3}$ can reduce $\mathrm{Cl}^{-}$uptake in mature citrus trees (Levy et al., 2000). Banuls and Primo-Millo (1992) compared the effects of increasing concentrations of soil-applied sodium chloride $(\mathrm{NaCl})$, potassium chloride $(\mathrm{KCl})$, and sodium nitrate $\left(\mathrm{NaNO}_{3}\right)$ on citrus photosynthesis and concluded that $\mathrm{NaCl}$ and $\mathrm{KCl}$ increased $\mathrm{Cl}^{-}$leaf content and reduced photosynthesis. $\mathrm{NaNO}_{3}$, however, did not reduce photosynthesis even though it increased leaf $\mathrm{Na}^{+}$to very high concentrations. Salinity-induced decreases in photosynthesis are almost always highly correlated with increases in leaf $\mathrm{Cl}^{-}$(Romero-Aranda and Syvertsen, 1996), but concomitant high concentrations of leaf $\mathrm{Na}^{+}$have also been related to low gas exchange rates (Lloyd et al., 1987).

\section{Salinity interactions with biotic stresses}

Much of the work on interactions between salinity and pathogens has been done using seedlings in a greenhouse, but salinity and phytophthora frequently have synergistic negative effects on budded trees in the field. The scion can affect the susceptibility of the rootstock to root rot (Shaked et al., 1984). Salinity stress may inhibit plant defense mechanisms against phytophthora (Afek and Sztejnberg, 1993) and decrease root regeneration under pathogen pressure. In greenhouse experiments, irrigation with high salinity water predisposed citrus rootstocks to attack by a group of root pathogens (Combrink et al., 1996). Rootstock seedlings of Troyer citrange (C. sinensis $x$ Poncirustrifoliata), Carrizo citrange, Volkamer lemon (C. volkamerianna), and rough lemon (C. jambhiri) were most affected by the treatment consisting of three root pathogens in combination [Phytophthora spp., Fusarium solani, and citrus nematode ( $T y$ lenchulus semipenetrans)] under saline conditions. Growth of these seedlings was significantly less when subjected to both the group of pathogens and salinity stress together than when seedlings were subjected to the pathogens or salt stress alone. The ability of phytophthora to tolerate high levels of salinity could significantly diminish the resistance of phytophthora-tolerant rootstocks under saline conditions (Blaker and 
MacDonald, 1986), especially since saturated soils and salinity stress can frequently occur together.

Nematodes. The citrus nematode can reduce the salt tolerance of citrus roots and increase $\mathrm{Cl}^{-}$uptake (Willers and Holmden, 1980). LeafCl- levels of severely infected trees varied between $1.75 \%$ and $2.00 \%$ compared to only $0.50 \%$ to $0.90 \%$ in less infected trees under the same conditions. This was true for salinity-tolerant rootstocks and for salinity-sensitive rootstocks. Nematodes increased more than 3fold the $\mathrm{Cl}^{-}$concentration in leaves but decreased the $\mathrm{Cl}^{-}$concentration in roots (Mashela and Nthangeni, 2002). Thus, nematode infection modified the allocation patterns of $\mathrm{Cl}^{-}$within citrus trees. Soil salinity apparently caused a breakdown in root chemical defenses (Dunn et al., 1998) and increased the susceptibility of citrus roots to attack by the citrus nematode (Mashela et al., 1992b). In addition, intermittent salinity stress increased the nematode population densities more than continuous irrigation with saline water (Mashela et al., 1992a).

Mycorrhizae. Citrus is very dependent on vesicular arbuscular mycorrhizae (VAM) colonization, especially under conditions of low soil phosphorus $(\mathrm{P})$ concentration or sterilized soils (Krikun and Levy, 1980). VAM can increase $\mathrm{P}$ and plant growth particularly in arid soils (Jeffries et al., 2002) or under saline conditions and thus alleviate salinity stress. However, VAM throughout the root system can also increase the concentrations of $\mathrm{Cl}^{-}$in leaves and roots of sweet orange and sour orange seedlings irrigated with high salinity water (Graham and Syvertsen, 1989). This increase could not be attributed to increased transpiration in the VAM plants. Salinized VAM plants of Carrizo citrange and sour orange accumulated more $\mathrm{Cl}^{-}$in leaves than non-mycorrhizal plants but $\mathrm{Cl}^{-}$was higher in non-mycorrhizal roots of sweet orange and Carrizo citrange than in VAM roots (Hartmond et al., 1987). On the other hand, leaf $\mathrm{Na}^{+}$concentrations were not affected by VAM. Natural VAM in relatively saline soils may be sensitive to salinity and its population decreased with increased soil salinity (Levy et al., 1983). VAM strains that originated in soils of different salinities may differ in this respect (Copeman et al., 1996; Juniper and Abbott, 1993).

\section{Potential benefits of moderate salinity}

Other than the benefits from moderate applications of fertilizer salts, salinity is usually not beneficial for citrus in the long run. Since citrus can tolerate moderate salinity and produce profitable yield using proper cultural practices and tolerant cultivars, there may be some short-term benefits from salinity including chilling/freezing tolerance, reduced water use and increase flowering.

Drought stress can substitute for cool wintertime temperatures to enhance cold hardiness (Yelenosky, 1979). Apparent drought stress from moderate salinity at levels of 30 to 60 $\mathrm{mol} \cdot \mathrm{m}^{-3}$ of $\mathrm{NaCl}$ applied for 2 months, reduced growth and total plant transpiration but enhanced cold hardiness of sweet orange and Cleopatra mandarin seedlings (Syvertsen and Yelenosky, 1988 ) even though osmotic potential and leaf proline concentration did not change significantly. Thus, controlled salinity stress under greenhouse conditions can substitute for cool temperature-induced freeze tolerance in seedlings by reducing physiological activity and growth. This phenomenon may be a matter of degree, however, since young grapefruit (C. paradisi) trees on different rootstocks with high $\mathrm{Cl}^{-}$content were more susceptible to freeze injury than those with low $\mathrm{Cl}^{-}$(Peynado, 1982).

Du Plessis (1985) suggested that reduced transpiration caused by salinity stress could potentially be a benefit for reducing the accumulation of soil salinity since the lower water uptake should increase the leaching fraction. This implies that an increase in the leaching fraction occurs when irrigating with saline water scheduled at the same frequency as non-saline water. However, soil salinity usually increases proportionally to the salinity in the irrigation water and thereby reduces growth and yield.

Just as drought stress can substitute for cool wintertime temperatures to enhance flower induction (Nir et al., 1972; Southwick and Davenport, 1986), it is possible that moderate salinity stress will also increase flowering. In a warm, wet climate with inadequate chilling or drought stress to maximize flower induction, controlled salinization might offer a substitute to induce flowering in citrus. Such a practice is used to induce flowering of litchee (Litchi chinensis) in Thailand (E. Tomer, personal communication) and low levels of salinity can increase flowering in several cultivars of avocado (Persea spp.) (Downton, 1978) and pear (Pyrus spp.) (Okubo et al., $2000)$ trees. If moderately saline irrigation water could be applied during induction followed by adequate rainfall or good quality irrigation water during fruit set, yields might be increased. The successful economic use of such a practice, however, remains to be tested.

\section{Conclusions}

There are many things citrus growers can do to ameliorate problems associated with salinity stress-from choosing the best rootstock and scion cultivars to appropriately managing irrigation and fertilizer application methods (Levy and Syvertsen, 2004). Salinity tolerance is a whole plant phenomenon that requires an appreciation of citrus rootstock/scion interactions in the field. Such relationships are complicated by interactions between salinity with other physical environmental factors and also with biotic pests and diseases. There are direct and indirect interactions between salinity, leaf water relations, pests and diseases that almost always have synergistic effects on citrus. To help citrus growers cope with salinity problems, researchers should study the underlying mechanisms of salinity tolerance and understand the mode of interaction with biotic stresses. An understanding of mechanisms of salinity tolerance will also benefit researchers developing new rootstocks with improved salinity tolerance. Not all effects of salinity are negative, however, as moderate short-term osmotic stress can reduce physiological activity and growth allowing citrus seedlings to survive cold stress, reduce water use and increase flowering.

\section{Literature cited}

Afek, U. and A. Sztejnberg. 1993. Temperature and gamma irradiation effects on scoparone, a citrus phytoalexin conferring resistance to Phytophthora citrophthora. Phytopathology 83:753-758.

Ball, M.C. and R. Munns. 1992. Plant responses to salinity under elevated atmospheric concentrations of $\mathrm{CO}_{2}$. Austral. J. Bot. 40:515-525. 
Banuls, J. and E. Primo-Millo. 1992. Effects of chloride and sodium on gas exchange parameters and water relations of Citrus plants. Physiol. Plant. 86:115-123.

Blaker, N.S. and J.D. MacDonald. 1986. The role of salinity in the development of phytophthora root rot of citrus. Phytopathology 76:970-975.

Castle, W.S., D.P.H. Tucker, A.H. Krezdorn, and C.O. Youtsey. 1993. Rootstocks for Florida citrus: Rootstock selection, the first step to success. 2nd ed. Univ. of Florida, Inst. Food Agr. Sci., Gainesville.

Combrink, N.J.J., N. Labuschagne, and R.O. Barnard. 1996. Predisposing effect of chloride on root disease caused by Fusarium solani, Phytophthora nicotianae, and Tylenchulus semipenetrans on four citrus rootstocks. Appl. Plant Sci. 10:5-9.

Copeman, R.H., C.A. Martin, and J.C. Stutz. 1996. Tomato growth in response to salinity and mycorrhizal fungi from saline or nonsaline soils. HortScience 31:341-344.

Downton, W.J.S. 1978. Growth and flowering in salt-stressed avocado trees. Austral. J. Agr. Res. 29:523-534.

Du Plessis, H.M. 1985. Evapotranspiration of citrus as affected by soil water deficit and soil salinity. Irr. Sci. 6:51-61.

Dunn, D.C., L.W. Duncan, and J.T. Romeo. 1998. Changes in arginine, PAL activity, and nematode behavior in salinity-stressed citrus. Phytochemistry 49:413-417.

Gomez-Cadenas, A., F.R. Tadeo, E. PrimoMillo, and M. Talon. 1998. Involvement of abscisic acid and ethylene in the responses of citrus seedlings to salt shock. Physiolog. Plant. 103:475-484.

Gomez-Cadenas, A., V. Arbona, J. Jacas, E. Primo-Millo, and M. Talon. 2002. Abscisic acid reduces leaf abscission and increases salt tolerance in citrus plants. J. Plant Growth Regulat. 21:234-240.

Graham, J.H. and J.P. Syvertsen. 1989. Vesicular arbuscular mycorrhiza increase chloride concentration in citrus seedlings. New Phytol. 113:29-36.

Hartmond, U., N.V. Schaesberg, J.H. Graham, and J.P. Syvertsen. 1987. Salinity and flooding stress effects on mycorrhizal and nonmycorrhizal citrus rootstock seedlings. Plant Soil 104:37-43.

Jeffries, P., A. Craven-Griffiths, J.M. Barea, Y. Levy, and J.C. Dodd. 2002. Application of arbuscular mycorrhizal fungi in the revegetation of desertified Mediterranean ecosystems, p. 151-174. In: S. Gianinazzi, H. Schüepp, J.M. Barea, and K. Haselwandter (eds.). Mycorrhizal technology in agriculture. From genes to bioproducts. Birkhäuser Verlag, Basel, Switzerland.

Jifon, J. and J.P. Syvertsen. 2001. Effects of moderate shade on citrus leaf gas exchange, fruit yield, and quality. Proc. Forida State Hort. Soc. 114:177-181.
Jifon, J. and J.P. Syvertsen. 2003a. Moderate shade can increase net gas exchange and reduce photoinhibition in citrus leaves. Tree Physiol. 23:119-127.

Jifon, J. and J.P. Syvertsen. 2003b. Kaolin particle film applications can increase photosynthesis and water use efficiency of ruby red grapefruit leaves. J. Amer. Soc. Hort. Sci. 128:107-112.

Juniper, S. and L. Abbott. 1993. Vesicular-arbuscular mycorrhizas and soil-salinity. Mycorrhiza 4:45-57.

Krikun, J. and Y. Levy. 1980. Effect of vesicular arbuscular mycorrhiza on citrus growth and mineral composition. Phytoparasitica 8:195-200.

Levy, Y., E. Raveh and J. Lifshitz. 2000. The effect of rootstock and nutrition on the response of grapefruit trees to salinity. Proc. Intl. Soc. Citricult. 1:334-337.

Levy, Y., J. Dodd, and J. Krikun. 1983. Effect of irrigation, water salinity and rootstock on the vertical distribution of vesicular arbuscular mycorrhiza in citrus roots. New Phytol. 95:397-403.

Levy, Y. and J.P. Syvertsen. 2004. Irrigation water quality and salinity effects in citrus trees. Hort. Rev. 30:37-82.

Lloyd, J., J.P. Syvertsen, and P.E. Kriedemann. 1987. Salinity effects on leaf water relations and gas exchange of 'Valencia' orange, Citrus sinensis (L.) Osbeck, on rootstocks with different salt exclusion characteristics. Austral. J. Plant Physiol. 14:605-617.

Maas, E.V. 1986. Salt tolerance in plants. Appl. Agr. Res. 1:12-26.

Mashela, W.P., L.W. Duncan, J.H. Graham, and R. McSorley. 1992a. Leaching soluble salts increases population densities of Tylenchulus semipenetrans. J. Nematol. 24:103-108.

Mashela, W.P., L.W. Duncan, and R. McSorley. 1992b. Salinity reduces resistance to Tylenchulussemipenetransin citrus rootstocks. Nematropica 22:7-12.

Mashela, W.P. and M.E. Nthangeni. 2002. Interaction effects of citrus rootstocks, salinity, and Tylenchulus semipenetrans parasitism on osmotically active ions. J. Phytopathol. 150:60-64.

Moya, J.L., A. Gomez-Cadenas, E. PrimoMillo, and M. Talon. 2003. Chloride absorption in relative salt sensitive Carrizo citrange and in salt tolerant Cleopatra mandarin citrus rootstocks is linked to water use. J. Expt. Bot. 54:825-833.

Nieves, M., A. Cerda, and M. Botella. 1991. Salt tolerance of two lemon scions measured by leaf chloride and sodium accumulation. J. Plant Nutr. 14:623-636.

Nir, I., R. Goren, and B. Leshem. 1972. Effects of water stress, gibberellic acid and 2-chloroethyltrimethylammoniumchloride (CCC) on flower differentiation in 'Eureka' lemon trees. J. Amer. Soc. Hort. Sci. 97:774-778.
Okubo, M., Y. Furukawa, and T. Sakuratani. 2000. Growth, flowering and leaf properties od pear cultivars grafted on two Asian pear rootstock seedlings under $\mathrm{NaCl}$ irrigation. Scientia Hort. 85:91-101.

Peynado, A. 1982. Cold hardiness of young 'Ruby Red' grapefruit trees as influenced by rootstock, trickle and flood irrigation, and chloride and boron in the irrigation water. J. Rio Grande Valley Hort. Soc. 35:149-157.

Rengel, Z. 1992. The role of calcium in salt toxicity. Plant Cell Environ. 15:625-632.

Romero-Aranda, R. and J.P. Syvertsen. 1996. The influence of foliar-applied urea nitrogen and saline solutions on net gas exchange of citrus leaves. J. Amer. Soc. Hort. Sci. 121:501-506.

Romero-Aranda, R., T. Soria, and J. Cuartero. 2002. Greenhouse mist improves yield of tomato plants grown under saline conditions. J. Amer. Soc. Hort. Sci. 127:644-648.

Shaked, A., S. Ashkenasi, and Y. Oren. 1984. Relationship between the occurrence of Phytophthora sp. root rots in young nucellar citrus trees and the inoculation with the viral complex containing exocortis viroid. Proc. Intl. Soc. Citricult. 2:430-432.

Shalhevet, J. and Y. Levy. 1990. Citrus trees, p. 951-986. In: A.R. Stewart and D.R. Nielsen (eds.). Irrigation of agricultural crops. Vol. 30, Amer. Soc. Agr., Crop Sci. Soc. Amer., Soil Sci. Soc. Amer., Madison, Wis.

Southwick, A. and T.L. Davenport. 1986 Characterization of water stress and low temperature effects on flower induction in citrus. Plant Physiol. 81:26-29.

Syvertsen, J.P. and L.G. Albrigo. 1980. Some effects of grapefruit tree canopy position on microclimate water relations, fruit yield, and juice quality. J. Amer. Soc. Hort. Sci. 105:454-459.

Syvertsen, J.P. and M.L. Smith, Jr. 1983. Environmental stress and seasonal changes in proline concentration of citrus tree tissues and juice. J. Amer. Soc. Hort. Sci. 108:861-866.

Syvertsen, J.P. and G. Yelenosky. 1988. Salinity can enhance freeze tolerance of citrus rootstock seedlings by modifying growth, water relations, and mineral nutrition. J. Amer. Soc. Hort. Sci. 113:889-893.

Willers, P. and E. Holmden. 1980. The influence of citrus nematode, Tylenchulus semipenetrans, on the performance of trees growing under saline conditions. Subtropica $1: 13-16$.

Yelenosky, G. 1979. Water stress induced cold hardening of young citrus trees. J. Amer. Soc. Hort. Sci. 104:270-273. 